\title{
Proposed Amendments to the AOA Constitution
}

https://doi.org/10.1515/jom-2021-8888

Published online May 10, 2021

The Chief Executive Officer of the American Osteopathic Association has arranged for their posting on the AOA's website, and distribution to the specialty and divisional societies that will be eligible to send representatives to the AOA's House of Delegates, which will occur on July 16-18, 2021.

The following proposed amendments to the AOA Constitution will be presented for first reading at the 2021 Annual Meeting.

Old material is crossed out and new material is capitalized.

\section{Article IX - Amendments - First Read for July 2021}

This Constitution may be amended by the House of Delegates at any annual meeting by a two-thirds vote of the total number of delegates accredited for voting, provided that such amendments shall have been presented to the House and filed with the Chief Executive Officer at a previous annual meeting, who shall cause them to be distributed by US mail or electronic mail, to each divisional and specialty society entitled to and voting representatives to the House of Delegates, posted on the AOA's website, and published in the on-line edition of the Journal of OSTEOPATHIC MEDICINE the Amean Osteopic Association not less than two months nor more than four months prior to the meeting at which they are to be acted upon.

\section{Article VIII - Section 1-C - First Read for July 2021}

One new physician in practice member elected by the House of Delegates to serve for one year. Candidates for the new physician in practice position shall be osteopathic physicians who have completed their postdoctoral training within the past five years ecene

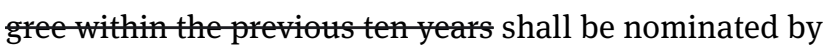
the council AOA Constitution \& Bylaws of new physicians in practice.

\section{Article $\mathrm{VI}$ - House of Delegates, Section 1B - First Read for July 2021}

Student Eounil Representation in Divisional Societies: Divisional societies shall be awarded one additional delegate as a student representative for each college of osteopathic medicine accredited by this Association and located in the state represented by that divisional society, such student delegate to be elected according to the Bylaws of the American Osteopathic Association.

The following proposed amendments to the American Osteopathic Association (AOA) Constitution were presented for First Reading at the July 2020 annual meeting of the House of Delegates and will be presented for action at the 2021 Annual Meeting, which will occur on July 16-18, 2021. The Chief Executive Officer of the American Osteopathic Association has arranged for their posting on the AOA's website, publication in the on-line edition of the Journal of Osteopathic Medicine ( $\mathrm{f} / \mathrm{k} / \mathrm{a}$ The Journal of the American Osteopathic Association) and distribution to the specialty and divisional societies that will be eligible to send representatives to the AOA's House of Delegates

All amendments require a two-thirds vote by the House of Delegates for approval.

Old material is crossed out and new material is capitalized.

\section{Article IX - Amendments}

This Constitution may be amended by the House of Delegates at any annual meeting by a two-thirds vote of the 
total number of delegates accredited for voting, provided that such amendments shall have been presented to the House and filed with the Chief Executive Officer at a previous annual meeting, who shall cause them to be distributed by US MAIL OR ELECTRONIC firstelass mail, pestage prepaid, to each divisional and specialty society entitled to and voting representatives to the House of Delegates, posted on the AOA's website, and published in the ON-LINE EDITION OF THE Journal of the American Osteopathic Association not less than two months Nor more than four months prior to the meeting at which they are to be acted upon.

\section{Article VIII - Board of Trustees and Executive Committee, Section 2 - Executive Committee}

The Executive Committee of this Association shall consist of the President, President-elect, Past Presidents for the preceding two years, the chairs of the Departments of Affiliate Relations, FINANCE Business Affairs, EDUCATION Edueational Affairs, Governmental Affairs, MEMBERSHIP Professional Affairs, and Research, Quality and Public Health. 